\title{
Analysis and study on the petroleum pollution characteristics of the typical petrochemical wharf in Tianjin port ${ }^{*}$
}

\author{
Xin-Hai Wang, Jin-Feng Bai and Hang Yu \\ Tianjin Research Institute for Water Transport Engineering, \\ Tianjin, P.R. China \\ Email:tksgcb_wxh@163.com
}

\begin{abstract}
Through sampling and analyzing seawater and sediment in typical port, the concentration distribution of petroleum hydrocarbon was obtained. According to the sampling data, the concentration rang of petroleum hydrocarbons is $0.009-0.065 \mathrm{mg} / \mathrm{L}$ in seawater. The concentration rang is 33.97-297.7 ten to the minus sixth $\mathrm{mg} / \mathrm{L}$ in sediments. In study, the pollution characteristic of petroleum hydrocarbons was well known in Nanjiang port. At the same time, the pollution status of petroleum hydrocarbon was preliminary comprehended in Tianjin harbor area. Besides, this study will provide a technology basis for the follow-up research on the prevention and remediation of the oil pollution.

Keywords: Tianjin Port; Petrochemical Wharf; Petroleum Hydrocarbons; Pollution Characteristics.
\end{abstract}

\section{Research Area}

Tianjin Nanjiang port is one of the four biggest ports of Tianjin port, which is located in the north side of Dagu waterway of the Haihe estuary and south side of the Tianjin port channel. It is about $12.5 \mathrm{~km}$ length in west-east direction, 1.3 - 2.0km width in north-south direction and $14.7-20 \mathrm{~km}^{2}$ areas. Up to now, it has 15 production berths and 135 million tons currency capacity. In the Nanjiang port, there are the deep-water area of bulk liquid cargo, Bohai petroleum base and operation zone of bulk dry cargo and so on. Among them, the deep-water area of bulk liquid cargo will be used as the transport and storage places of crude oil, refined oil and other liquid chemicals for the near future. The Nanjiang port is a representative area of Tianjin harbor for the petroleum pollution study, taking into account of the bulk foreign trade oil in Nanjiang port. Therefore, the Nanjiang port was chosen as the research object of the petroleum contamination characteristics.

\footnotetext{
* This study was supported by the basic scientific research project of the central level public welfare research institute TKS140212.
} 


\section{Layout of Sampling Stations}

This survey area of petroleum hydrocarbons was chosen in Nanjiang port. The survey was carried out in the autumn of 2014 and in the spring of 2015 respectively, including spring tide and neap tide sampling survey. There were 7 sampling stations in total in this survey. All of stations had seawater sampling from the sea surface, and only four stations of them synchronous had sediment sampling. The location of sampling stations can be seen in Figure 1. The collection, storage, transportation of the samples was performed in accordance with the requirements of the Specification for Marine Monitoring [1-2] and the Specification for Oceanographic Survey [3].

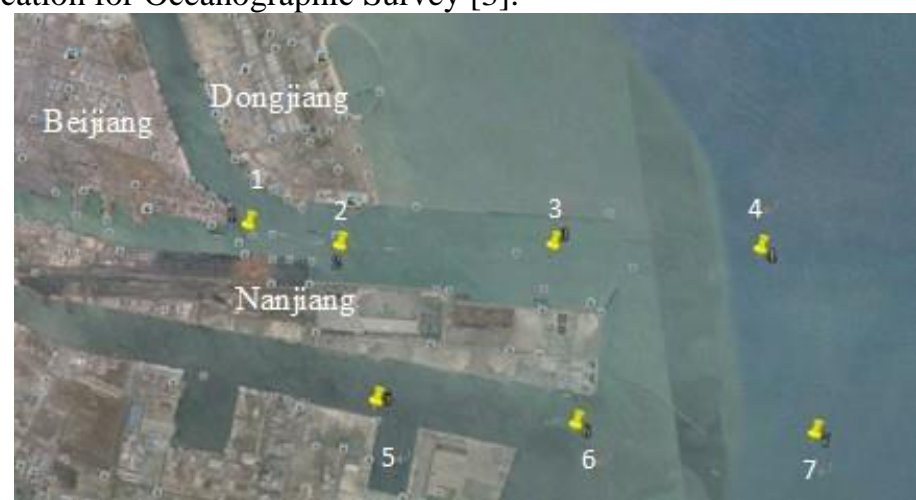

Fig. 1. The location of the sampling stations in Nanjiang port.

\section{Analysis on the Status of Petroleum Hydrocarbon Pollution}

\subsection{Analysis of petroleum hydrocarbon pollution in seawater}

The petroleum concentration of the ebb and rising tide in spring and autumn was been got, by sampling and analyzing of petroleum hydrocarbons of Nanjiang port seawater. The concentration graph of petroleum hydrocarbon is given in Figure 2 and Figure 3.
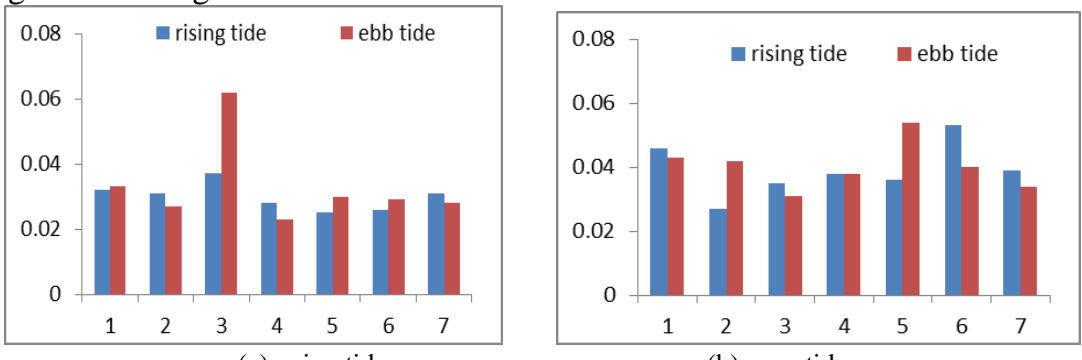

(a)spring tide

(b) neap tide

Fig. 2. Petroleum concentration graph of each station in the autumn seawater (unit: $\mathrm{mg} / \mathrm{L}$ ) 


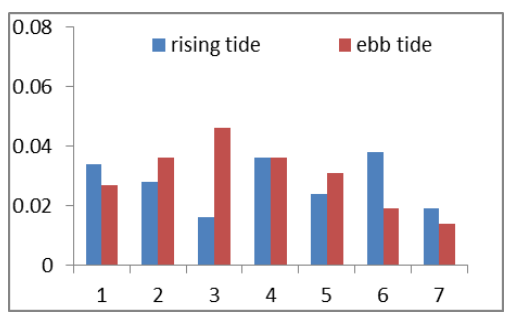

(a)spring tide

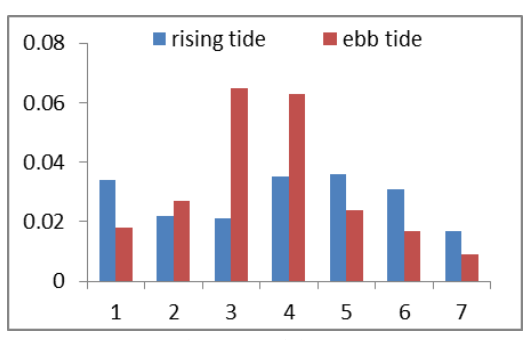

(b) neap tide

Fig. 3. Petroleum concentration graph of each station in the spring seawater (unit: $\mathrm{mg} / \mathrm{L}$ )

The sampling data is shown as follows. The petroleum hydrocarbon concentration is $0.025-0.037 \mathrm{mg} / \mathrm{L}$ of rising tide and $0.023-0.062 \mathrm{mg} / \mathrm{L}$ of ebb tide in autumn in spring tide. The petroleum hydrocarbon concentration is $0.027-0.053 \mathrm{mg} / \mathrm{L}$ of rising tide and $0.031-0.054 \mathrm{mg} / \mathrm{L}$ of ebb tide in autumn in neap tide. The petroleum hydrocarbon concentration is $0.016-0.038 \mathrm{mg} / \mathrm{L}$ of rising tide and $0.014-0.046 \mathrm{mg} / \mathrm{L} \mathrm{mg} / \mathrm{L}$ of ebb tide in spring in spring tide. The petroleum hydrocarbon concentration is $0.017-0.036 \mathrm{mg} / \mathrm{L}$ of rising tide and $0.009-0.065 \mathrm{mg} / \mathrm{L}$ of ebb tide in spring in neap tide. The concentration of all stations can meet the water quality standard, so the sea is not polluted.

At the same time, the further analysis shows that the concentration was lower than the third level standard [4] in all stations and the entire sampling time interval. However, the concentration is higher than the second level standard in three stations of all seven stations in autumn. So 42.9 percent stations were more than the second level standard, and nearly half of the stations are more than the second level. Meanwhile, the concentration is higher than the second level standard in two stations of all seven stations in spring. So 28.6 percent stations were more than the second level standard. Moreover, the maximum excess times were respectively $0.24,0.06,0.087$ times in the autumn and 0.3 times in the spring in Nanjiang port. From the above, it can be seen that the station numbers and the excess times of higher the second level petroleum concentration is higher, especially in the spring.

\subsection{Analysis of petroleum hydrocarbon pollution in sediments}

The petroleum concentration of the ebb and rising tide in spring and autumn was been got, by sampling and analyzing of petroleum hydrocarbons of Nanjiang port sediment. The concentration graph of petroleum hydrocarbon is given in Figure 4 and Figure 5. 


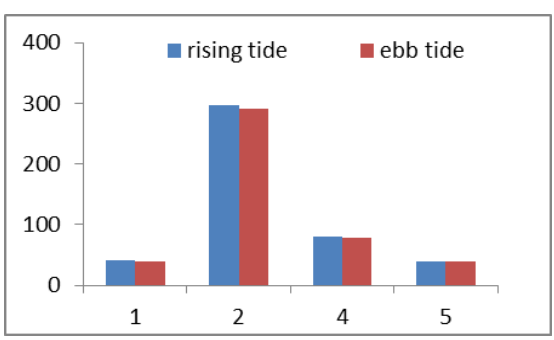

(a)spring tide

Fig. 4. Petroleum concentration graph of each station in the autumn sediment (unit: 10-6 mg/L).

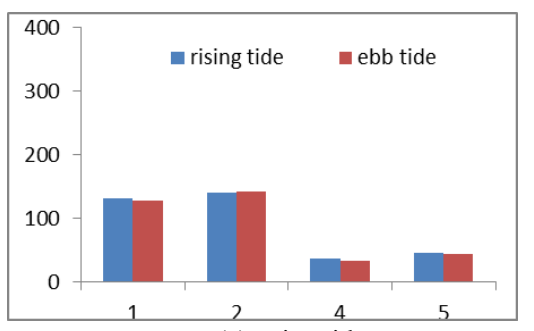

(a)spring tide

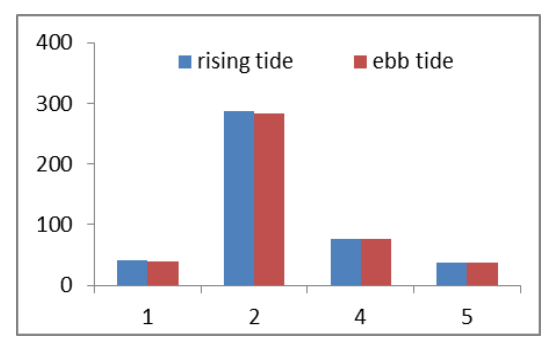

(b) neap tide

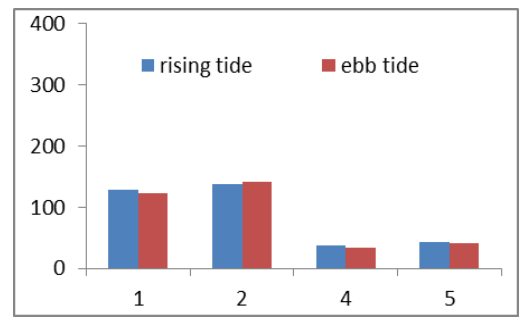

(b) neap tide

Fig. 5. Petroleum concentration graph of each station in the spring sediment (unit: $10-6 \mathrm{mg} / \mathrm{L}$ ).

The sampling data is shown as follows. The petroleum hydrocarbon concentration is $39.42-297.76$ ten to the minus sixth $\mathrm{mg} / \mathrm{L}$ of rising tide and 39.78-291.81 ten to the minus sixth $\mathrm{mg} / \mathrm{L}$ of ebb tide in autumn in spring tide. The petroleum hydrocarbon concentration is $38.14-287.87$ ten to the minus sixth $\mathrm{mg} / \mathrm{L}$ of rising tide and 37.28-283.06 ten to the minus sixth $\mathrm{mg} / \mathrm{L}$ of ebb tide in autumn in neap tide. The petroleum hydrocarbon concentration is 36.66-139.71 ten to the minus sixth $\mathrm{mg} / \mathrm{L}$ of rising tide and 33.97-141.89 ten to the minus sixth $\mathrm{mg} / \mathrm{L}$ of ebb tide in spring in spring tide. The petroleum hydrocarbon concentration is $37.87-137.72$ ten to the minus sixth $\mathrm{mg} / \mathrm{L}$ of rising tide and 34.53-140.69 ten to the minus sixth $\mathrm{mg} / \mathrm{L}$ of ebb tide in spring in neap tide. The concentration of all sampling stations not only can meet the water quality standard, but also it is lower than the first level standard [5]. So the sediment condition is good.

\section{Conclusions}

The research region is confirmed in Nanjiang port for its large oil transport. In this survey, seven stations were located to sample the seawater and sediment, meanwhile the petroleum concentration was got. Furthermore, the station numbers and the excess times were analyzed. On the basis of sampling data, the concentration rang of petroleum hydrocarbons is $0.009-0.065 \mathrm{mg} / \mathrm{L}$ in seawater. Moreover, the station numbers and the highest times reached $42.9 \%$ and 0.3 
times, which is super the second level standard. It is obvious that the petroleum concentration is higher in seawater. Similarly, the concentration rang of petroleum hydrocarbons is 33.97-297.76 ten to the minus sixth mg/L in Sediments. Furthermore, the concentration of all sampling stations not only can meet the s5 ediment quality standard, but also is lower than the first level standard. So the sediment condition is good.

Through this study, firstly, the present situation of petroleum hydrocarbon was analyzed in seawater and in sediment. Secondly, the pollution characteristic of petroleum hydrocarbons was well known in Nanjiang port. Thirdly, the petroleum hydrocarbon pollution status of Tianjin harbor area was preliminary comprehended. Besides, this study will provide a basis for the follow-up research on the prevention and remediation of oil pollution.

\section{References}

1. Liu Jinlei. Petroleum contaminants in seawater and their bioremediation. Transactions of oceanology and limnology. 2006, pp: 48-57.

2. The specification for marine monitoring (GB 17378-1998).

3. Specifications for oceanographic survey (GB 12763-1999).

4. Sea water quality standard (GB 3097-1997).

5. Marine Sediment Quality (GB18668-2002. 